OPEN ACCESS

Edited by: Joanna Bowtell, University of Exeter, United Kingdom

Reviewed by:

Laurent Mosoni, Institut national français de l'agriculture, de l'alimentation et de l'environnement, France Oliver C. Witard,

King's College London, United Kingdom

*Correspondence:

Daniel R. Moore

dr.moore@utoronto.ca

Specialty section: This article was submitted to Sport and Exercise Nutrition,

a section of the journa Frontiers in Nutrition

Received: 11 December 2020 Accepted: 19 May 2021

Published: 09 June 2021

Citation: Williamson E and Moore DR (2021) A Muscle-Centric Perspective on Intermittent Fasting: A Suboptimal Dietary Strategy for Supporting Muscle Protein Remodeling and Muscle Mass? Front. Nutr. 8:640621. doi: 10.3389/fnut.2021.640621

\section{A Muscle-Centric Perspective on Intermittent Fasting: A Suboptimal Dietary Strategy for Supporting Muscle Protein Remodeling and Muscle Mass?}

\author{
Eric Williamson and Daniel R. Moore* \\ Faculty of Kinesiology and Physical Education, University of Toronto, Toronto, ON, Canada
}

Muscle protein is constantly "turning over" through the breakdown of old/damaged proteins and the resynthesis of new functional proteins, the algebraic difference determining net muscle gain, maintenance, or loss. This turnover, which is sensitive to the nutritional environment, ultimately determines the mass, quality, and health of skeletal muscle over time. Intermittent fasting has become a topic of interest in the health community as an avenue to improve health and body composition primarily via caloric deficiency as well as enhanced lipolysis and fat oxidation secondary to attenuated daily insulin response. However, this approach belies the established anti-catabolic effect of insulin on skeletal muscle. More importantly, muscle protein synthesis, which is the primary regulated turnover variable in healthy humans, is stimulated by the consumption of dietary amino acids, a process that is saturated at a moderate protein intake. While limited research has explored the effect of intermittent fasting on muscle-related outcomes, we propose that infrequent meal feeding and periods of prolonged fasting characteristic of models of intermittent fasting may be counter-productive to optimizing muscle protein turnover and net muscle protein balance. The present commentary will discuss the regulation of muscle protein turnover across fasted and fed cycles and contrast it with studies exploring how dietary manipulation alters the partitioning of fat and lean body mass. It is our position that intermittent fasting likely represents a suboptimal dietary approach to remodel skeletal muscle, which could impact the ability to maintain or enhance muscle mass and quality, especially during periods of reduced energy availability.

Keywords: intermittent fasting, muscle protein metabolism, dietary protein, muscle mass, weight loss, muscle protein synthesis/breakdown, lean body mass, time-restricted eating

\section{INTRODUCTION}

Skeletal muscle's central role is the production of contractile force. However, this tissue also serves as the primary site of postprandial glucose disposal (1) and is the largest contributor to resting energy expenditure (2), which collectively positions it as a vital tissue for the maintenance of health and function. Muscle is a dynamic tissue in a constant state of turnover as characterized by 
rates of muscle protein synthesis (MPS) and muscle protein breakdown (MPB). These processes are responsive to nutrients and contractile activity with changes in MPS and MPB ultimately influencing muscle tissue mass, quality, and health, all of which can influence physical performance (3), injury prevalence (4), and disease risk and/or progression in clinical populations (5).

MPB, which is primarily influenced by the suppressive effect of insulin (6), serves to eliminate old, damaged, mutated and/or redundant proteins through breakdown into their constituent amino acids (AA) (7). These liberated AA enter the muscle's free intracellular pool whereby they may serve as a fuel source (e.g., oxidative phosphorylation) or precursors to be recycled back into protein synthesis. Intramuscular free AA can also be released into circulation to be used by other tissues for synthesis, oxidation or as substrates for gluconeogenesis or ketogenesis (e.g., in the liver), the latter of which is irreversible and contributes to net AA loss. The prevailing view is that MPB plays a relatively minor role in the regulation of muscle mass in healthy humans (7), although whole body protein breakdown that is influenced by higher turning over non-muscle protein pools may play a greater role in whole body net protein balance (8).

MPS is the sequencing of individual AA, made available through protein breakdown or exogenous sources (e.g., digestion and absorption of dietary protein/AA), into polypeptide chains that form the functional protein of muscle tissue. When MPS exceeds MPB, a positive muscle net protein balance and, by extension anabolic environment, occurs. In healthy adults, MPS is generally the more responsive variable and is the primary mediator of muscle net protein balance (7) and long-term changes in muscle mass (9). However, MPS is also important for replacing old, damaged, and mutated tissue proteins to maintain muscle quality (10). Thus, the optimal stimulation of MPS ultimately influences the mass and quality of skeletal muscle, which may impact a variety of health and/or performance related factors including glucose utilization (1), resting and activity energy expenditure (11), and disease risk and mortality (12).

The dietary strategy of intermittent fasting (IF) has become a topic of interest as an avenue to improve health $(13,14)$ and is often divided into three subclasses: alternate-day fasting, wholeday fasting, and time-restricted eating (TRE) (14). Alternate-day fasting involves alternating between ad libitum feeding days and very low energy intake (e.g., a single meal containing $\sim 25 \%$ of daily calorie needs) or complete fasting days. Whole-day fasting typically consists of 1-2 days of either complete abstinence from calories or severe restriction on fasting days plus ad libitum eating on the other days. Finally, TRE, which arguably is the "mildest" form of IF, consists of restricting one's eating window to a certain number of hours per day often ranging from 4 to $8 \mathrm{~h}$ (14) with a suggested frequency of 1-3 meals (13). Thus, these IF strategies ultimately have a marked influence on the availability of postprandial dietary AA to support MPS and insulin to attenuate MPB.

Many of the health promoting effects of IF are mediated by its effectiveness to induce weight loss (15). For example, when IF is compared to controls with no intervention it generally results in weight loss $(16,17)$, although when compared to continuous energy restriction it is not superior in this outcome (18). By first principles, this suggests that IF may be an elementary means of inducing energy deficiency with no further diet modifications, which may in the short term enhance dietary adherence (19). This proposition is supported by the observation that skipping meals for up to 12 weeks is not compensated for by an increase in energy intake at subsequent meals consumed ad libitum (20). Additionally, $18 \mathrm{~h}$ compared to $12 \mathrm{~h}$ fasting has demonstrated significantly lower ghrelin levels, which could contribute to the reported reduced desire to eat and increased fullness over a $24 \mathrm{~h}$ period (21). Thus, as reduced energy availability can influence MPS rates (22,23), IF strategies would need to consider the impact of total energy intake as a potential confounder contributing to the postprandial regulation of muscle protein turnover.

The following discussion outlines the current understanding of muscle protein metabolism in relation to the anticipated effect of IF as a dietary strategy on muscle mass and remodeling.

\section{NUTRITIONAL REGULATION OF MUSCLE PROTEIN BREAKDOWN}

The breakdown and removal of muscle proteins is regulated by the ubiquitin-proteosome, calpain, and autophagy systems. While some benefits of IF are suggested to be mediated by increased autophagy (24), induction of this system with short term fasting (i.e., up to $36 \mathrm{~h}$ ) is not readily apparent in human skeletal muscle, unlike with exercise $(25,26)$. In contrast, the ubiquitin-proteosomal and calpain systems are the primary systems regulating nutrient and contraction-induced changes in MPB in humans (7) and therefore will be the primary focus of the present review. MPB is sensitive to feeding indirectly via the nutrient (i.e., carbohydrate and/or AA)-induced release of insulin from the pancreas (27). Maximal reductions in MPB require only modest elevations in plasma insulin concentrations (i.e., $\sim 15-30 \mathrm{mU} / \mathrm{L})(6,28)$, which can be stimulated with a modest carbohydrate or protein intake (i.e., $\sim 20-30 \mathrm{~g})(29,30)$. Thus, the postabsorptive state when insulin is low is characterized by the highest rates of MPB to supply free AA, which are primarily "stored" in skeletal-muscle proteins (31), for other tissues (32-34) and as gluconeogenic precursors $(31,35,36)$. This enhancement in MPB is demonstrated both with an overnight $(\sim 10 \mathrm{~h})$ fast $(31,35)$ and prolonged $(60-72 \mathrm{~h})$ fasting $(36-38)$. Given that IF typically involves a relatively prolonged fasting period (i.e., $\geq 16 \mathrm{~h}$ ) as a primary means to reduce systemic insulin and promote lipolysis, MPB would be greater over a $24 \mathrm{~h}$ period with IF as compared to more typical meal feeding (i.e., 3-5 meals over $\sim 16 \mathrm{~h}$ postprandrial period). With the contraction-induced anabolic stimulus of resistance exercise there is an increase in MPB, although this primarily serves to provide AA precursors to support MPS in the fasted state $(39,40)$. Thus, resistance exercise may help retain muscle mass with IF by attenuating the negative muscle protein balance of fasted, rested muscle. However, the exercise-induced increase in MPB is completely ablated with exogenous AA (41), highlighting an important role for dietary AA to support muscle anabolism via attenuated catabolism as well. 


\section{NUTRITIONAL REGULATION OF MUSCLE PROTEIN SYNTHESIS}

Dietary AA are the primary stimulators of and precursors for the synthesis of new muscle proteins (42). The equivalent of $\sim 0.25 \mathrm{~g} / \mathrm{kg}$ of leucine-enriched dietary protein in a single meal generally provides a saturating dose of AA for the postprandial stimulation of MPS (43-45), which persists for up to $6 \mathrm{~h}$ with the ingestion of whole foods (e.g., egg, beef and dairy proteins) (4652). Importantly, after attainment of peak MPS (i.e., $\sim 1.5-3 \mathrm{~h}$ after protein feeding) $(46,47,49,51,53)$, MPS gradually reverts back to basal levels even in the presence of sustained plasma aminoacidemia $(54,55)$. This is referred to as the "muscle full" effect (56) and demonstrates that there is a refractory period following ingestion of a protein bolus with the MPS pathway not able to be stimulated sequentially for $\sim 3-5 \mathrm{~h}$. Resistance exercise can prolong this postprandial muscle protein synthetic response (i.e., $>5 \mathrm{~h}$ ) (particularly of the myofibrillar fraction) $(57,58)$, although the maximal stimulatory protein dose is similar to what is sufficient at rest (i.e., $\sim 0.3 \mathrm{~g} / \mathrm{kg}$ ) (45). There is some evidence that energy deficiency may increase the acute meal protein intake required to maximize MPS $(22,59)$ with estimates of $\sim 0.4-0.5$ $\mathrm{g} / \mathrm{kg}$ being potentially sufficient (45). While protein and AA may have an insulinogenic effect (29), insulin only has a permissive effect for supporting maximal rates of MPS at rest and after exercise $(29,30,60)$. Thus, manipulating the amount and timing of dietary AA ingestion represents the most important nutritional variable to optimize MPS.

\section{NUTRITIONAL REGULATION OF AMINO ACID OXIDATION}

AA oxidation is generally low after an overnight fast but can increase with the duration of the fast (i.e., up to $3 \mathrm{~d}$ ) (37), which during a period of acute starvation would contribute to a negative whole body (61) and muscle protein balance (38). While meal protein ingestion initiates a normal postprandial increase in AA oxidation (62), dietary AA consumed in excess of their ability to be incorporated into new body (especially muscle) proteins are further irreversibly oxidized and their nitrogen excreted (43-45). It has been suggested that the protein dose required to enhance whole body anabolism may be substantially greater than that required at the level of the muscle $(63,64)$. Accordingly, it is theorized that AA may be sequestered in splanchnic tissue (primarily the gut) to be later broken down and made available for synthesis of other tissues including muscle (63), although this has yet to be demonstrated. Thus, it is arguably more beneficial to consume acute meal protein intakes that maximize MPS yet minimize AA oxidation in order to optimize the daily dietary protein efficiency. In support of this notion, a recent study (21) comparing a $6 \mathrm{~h}$ feeding window with 3 meals to a $12 \mathrm{~h}$ feeding window with three meals (protein intake of $\sim 0.3 \mathrm{~g} / \mathrm{kg}$ per meal), the $6 \mathrm{~h}$ feeding window had significantly increased rates of $24 \mathrm{~h}$ protein oxidation by $\sim 13 \mathrm{~g} / \mathrm{d}$ $(\sim 85$ vs. $\sim 71 \mathrm{~g} / \mathrm{d})$.

\section{DISCUSSION}

Research on IF is growing exponentially with $\sim 34$ and $\sim 45 \%$ of the $>600$ and $>200$ references since 2010 occurring in the past calendar year for the search terms "intermittent fasting" and "time-restricted eating," respectively (source: Pubmed ${ }^{\circledR}$; accessed December 11, 2020). A current limitation to the field of IF research is that no study, to the best of our knowledge, has measured muscle protein kinetics with alternate-day fasting or TRE. However, information may be gleaned from studies investigating the impact of daily feeding pattern on protein metabolism. For example, consuming a balanced pattern of moderate protein-containing meals (i.e., 3-4 meals at $\sim 0.25-$ $0.3 \mathrm{~g} / \mathrm{kg}$ per meal) supports greater rates of myofibrillar and mixed muscle protein synthesis $(65,66)$ as well as whole body net balance (67) at rest and during recovery from resistance exercise in energy balance as compared to larger less frequent meals or in a skewed distribution (i.e., majority of protein in a single meal). These longer acute trials (i.e., 12-24h) support the "muscle full" concept (56) that is exemplified by a maximal muscle protein synthetic response to acute protein ingestion (68). Collectively these acute studies support the concept that meal feeding pattern, irrespective of total protein intake, can influence whole body and muscle protein remodeling with large proteincontaining meals stimulating postprandial AA oxidization rather than muscle tissue synthesis (Figure 1). Thus, based on the acute research to date, we argue that the lost opportunity for AAinduced MPS with more feedings may not be compensated for with fewer feedings at higher doses, as what is likely to occur with IF.

To our knowledge, no studies have examined whether adaptations in MPB, MPS, and AA oxidation take place over time to an IF protocol. Available literature suggests that following an overnight fast, the first meal demonstrates a similar MPS response to other meals (65), including those preceded by a large protein containing mixed-meal $4 \mathrm{~h}$ prior (44). Also, no adaptation is observed in the MPS response after 7-days consuming a skewed distribution of daily protein intake (66), drawing into question whether adaptation may occur with prolonged fasting and/or a chronically altered dietary protein intake pattern such as with IF. Therefore, while we cannot discount that the MPS response may be greater with a meal that breaks a prolonged fasting window and/or that MPB may adapt to a lower set point with chronic IF, there is currently little evidence to support this thesis.

Randomized control trials analyzing the effect of IF on fat free mass (FFM) demonstrate similar $(19,69-81)$ outcomes compared to controls. As IF often results in negative energy balance and weight loss $(16,17)$, when IF is compared to continuous energy restriction some systematic reviews suggest similar (82) or enhanced (83) preservation of FFM. The divergence in some of these results may be due to the differences in the types of IF or the self-selected meal frequency by research participants. As discussed above, there is a broad range of IF protocols and those which result in fewer meals (e.g., whole-day) would have greater effects than those with more meals (e.g., TRE). It is also important to note that the length of the studies to date may not have been 


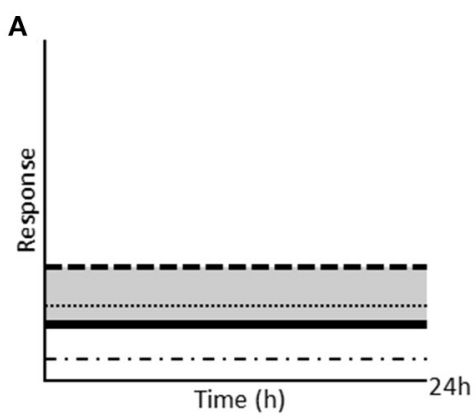

C

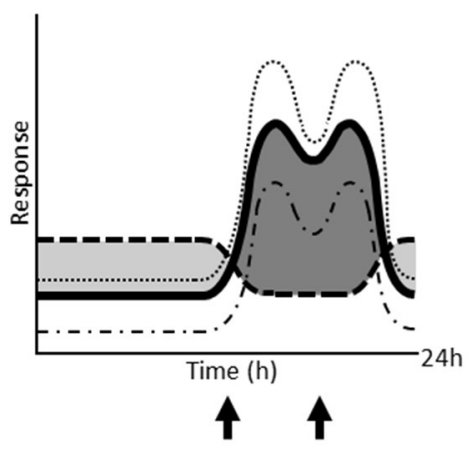

B

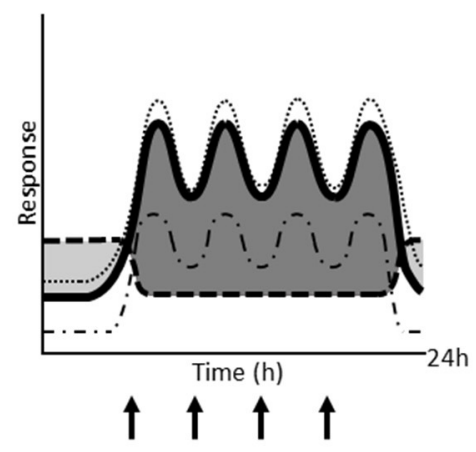

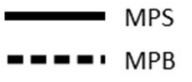

- =-1MPB

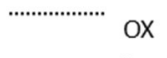

-.... Insulin

$\uparrow$ Meal

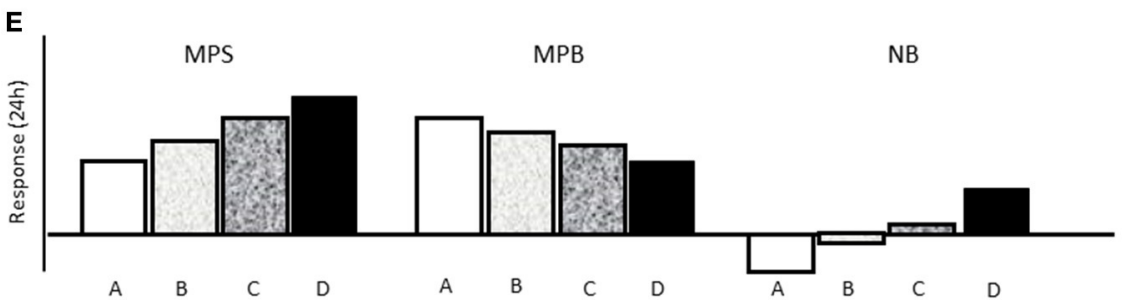

FIGURE 1 | Schematic representation of the effect of different types of IF on acute muscle protein kinetics. Changes in muscle protein synthesis (MPS) and breakdown, amino acid oxidation (OX), and circulating insulin concentration over $24 \mathrm{~h}$ at rest with whole day fasting (A), TRE with one meal (B), TRE with two meals over 6-8 $\mathrm{h}$ (C), and an unrestricted eating window $(\sim 16 \mathrm{~h})$ with balanced meal pattern (D). Size of arrows reflects the relative protein and energy content of each meal. Shaded dark gray areas indicate time in net positive protein balance and light gray areas indicate time in net negative protein balance, which are summarized as net $24 \mathrm{~h}$ response in MPS, MPB, and net muscle protein balance (NB; MPS-MPB) (E).

sufficient to elucidate differences in FFM given the sensitivity of body composition measurement modalities used and their ability to detect changes over short (i.e., $\leq 12$ weeks) interventions (84-86). Of note is a relative large recent study $(n=116$ adult participants) that reported reductions in appendicular FFM by dual-energy X-ray absorptiometry with TRE over 12 weeks (87), which may be more representative of skeletal muscle mass than total FFM (88). Many of the studies mentioned above prescribe variations of IF as the independent variable but do not explicitly control dietary intake $(19,69,70,72-78,81,89,90)$ and/or physical activity $(19,69-72,75-78,80,89,90)$, the latter of which is important to consider given that spontaneous physical activity may be modified by restricted eating (91) and can also influence the sensitivity of skeletal muscle to dietary AA (92). When IF is coupled with the potent anabolic stimulus of resistance exercise, a systematic review (93) observed no significant differences in FFM outcomes when compared to those resistance training with a normal diet. However, given the normal diet group also did not experience gains in FFM, as would be expected, the length (i.e., 48 weeks) of the included studies may also not have been adequate to reliably measure changes in FFM. It has been proposed that interventions $>8$ weeks are required for reliable FFM differences to become apparent with resistance training (94). In fact, a recent study suggests that resistance training-induced gains in FFM over 12 weeks are enhanced with a balanced as compared to a skewed daily protein distribution in healthy young men despite consuming a moderate (i.e., $1.3-1.45 \mathrm{~g} / \mathrm{kg} / \mathrm{d}$ ) protein intake (95), which could be lower than that which would maximize growth $(96,97)$. Collectively, research to date evaluating the impact of IF on changes in body composition in young adults with and without prescribed exercise is equivocal. Therefore, it is important to acknowledge that the hypothesis of IF having consequences for muscle mass in particular may be complex. Based on our current understanding of acute muscle protein 
metabolism, the potential effect of IF may be small relative to other lifestyle related variables (e.g., total protein intake and exercise) but could be meaningful when extrapolated over time. However, we acknowledge that acute measures of muscle protein metabolism in laboratory settings may be oversimplified and their relationship to muscle mass and/or muscle quality need further investigation (9).

A limitation in evaluating the impact of IF on muscle mass and function is the overreliance on whole body estimates of FFM, which have been questioned as to their ability to specifically delineate skeletal muscle mass given they include substantial organ and non-muscle lean tissue $(98,99)$. While including additional outcomes such as appendicular lean mass, muscle thickness, or cross-sectional area, and/or fiber characteristics would help address the consequences of IF on muscle mass, characterizing changes in muscle protein turnover has been suggested to be an effective means to "predict" the direction of change in muscle mass over time, especially if measured over days $(100,101)$. Therefore, future research should include muscle specific outcomes (e.g., measures of mass and/or function) in chronic, controlled diet trials and/or measures of muscle protein turnover in acute trials to more clearly establish the impact of IF on skeletal muscle quality.

If the hypothesis of more protein feedings per day being optimal for mass and remodeling based on the acute literature is true, IF may represent a dietary conundrum for some populations. While IF is often employed to reduce feeding intakes, restrict total energy intake, and maintain a low insulin profile to help mobilize and metabolize endogenous fat $(13,14)$, based on our current understanding of the acute, nutritional regulation of muscle protein turnover it seems antithetical to what would presumably optimize muscle protein synthesis and net muscle protein balance (as summarized in Figure 1). Critically, populations who may experience a level of "anabolic resistance" to dietary protein, such as sedentary obese (102) and/or older adults (103), may be further susceptible to the suboptimal muscle protein turnover and anabolic environment borne of IF. For example, older adults who consume a balanced daily protein intake and/or consume a greater number of meals containing adequate protein ingestion generally have greater leg lean mass and muscle strength (104). There is also evidence that reduced energy availability, which often occurs in tandem with IF $(16,17,20)$, increases the per meal protein intake required to maximize muscle protein synthesis $(22,23)$. Thus, while this would ostensibly favor larger protein meals that may be

\section{REFERENCES}

1. Thiebaud D, Jaccot E, Defronzo RA, Maeder E, Jequier E, Felber JP. The Effect of Graded Doses of Insulin on Total Glucose Uptake, Glucose Oxidation, and Glucose Storage in Man. Diabetes. (1982) 31:95763. doi: $10.2337 /$ diacare.31.11.957

2. Wang ZM, Ying Z, Bosy-Westphal A, Zhang J, Schautz B, Later W, et al. Specific metabolic rates of major organs and tissues across adulthood: Evaluation by mechanistic model of resting energy expenditure. Am J Clin Nutr. (2010) 92:1369-77. doi: 10.3945/ajcn.2010.29885 characteristic of TRE in particular, it does not preclude the need to consume protein more frequently, which would ultimately also help meet the higher recommended daily protein intakes that enhance muscle and FFM retention with weight loss $(59,105)$. Finally, performance populations such as athletes and military personnel may also be concerned with the quality of retained muscle/FFM with or without targeted weight loss (59), which would be important considerations for future research.

If the acute effects of IF lead to detrimental long-term outcomes for muscle, whole-day, and alternate-day fasting would have the greatest consequential effect on muscle mass and remodeling. This is due to the prolonged period with greater MPB and lower MPS compounded by the greater energy deficient state likely to occur (107) relative to TRE (108). In consideration of TRE, fewer meals would likely have a greater negative impact on muscle protein turnover (Figure 1). If TRE were to be employed, the hypothesis to improve muscle mass and remodeling suggests that protein intake should be consumed at a daily intake of at least $1.6 \mathrm{~g} / \mathrm{kg}$ and into the number of meals that the feeding window allows separated by $3-5 \mathrm{~h}$.

In conclusion, while IF may represent an option for a variety of populations to promote fat loss and improve aspects of metabolic health, additional research needs to focus on the impact of meal frequency on the quantity and quality of muscle mass. Inasmuch as IF may be purported as the enemy of body fat, future research must ensure this is not also the case for muscle. From our current understanding of muscle protein metabolism and taking a "muscle-centric" view for diet, we highlight that current acute evidence suggests IF may represent a counterproductive strategy to optimize muscle mass and, as far as protein turnover can remodel old/damaged proteins, muscle quality. Thus, studies that concurrently measure muscle protein metabolism and muscle mass and function will be instrumental in resolving these issues.

\section{DATA AVAILABILITY STATEMENT}

The original contributions presented in the study are included in the article/supplementary material, further inquiries can be directed to the corresponding author/s.

\section{AUTHOR CONTRIBUTIONS}

EW and DM wrote and revised the manuscript. Both authors read and approved the final version. 
signaling, ubiquitin ligases, and protein turnover in human muscle. $A m J$ Physiol Endocrinol Metab. (2008) 295:E595. doi: 10.1152/ajpendo.90411.2008

7. Tipton KD, Hamilton DL, Gallagher IJ. Assessing the role of muscle protein breakdown in response to nutrition and exercise in humans. Sport Med. (2018) 48(Suppl. 1):53-64. doi: 10.1007/s40279-017-0845-5

8. Kim I-Y, Schutzler S, Schrader A, Spencer HJ, Azhar G, Ferrando AA, et al. The anabolic response to a meal containing different amounts of protein is not limited by the maximal stimulation of protein synthesis in healthy young adults. Am J Physiol Metab. (2016) 310:E73E80. doi: 10.1152/ajpendo.00365.2015

9. Mitchell CJ, Churchward-Venne TA, Cameron-Smith D, Phillips SM. What is the relationship between the acute muscle protein synthesis response and changes in muscle mass? J Appl Physiol. (2015) 118:4957. doi: 10.1152 /japplphysiol.00609.2014

10. Layman DK, Anthony TG, Rasmussen BB, Adams SH, Lynch CJ, Brinkworth GD, et al. Defining meal requirements for protein to optimize metabolic roles of amino acids. Am J Clin Nutr. (2015) 101:13308. doi: 10.3945/ajcn.114.084053

11. Zurlo F, Larson K, Bogardus C, Ravussin E. Skeletal muscle metabolism is a major determinant of resting energy expenditure. J Clin Invest. (1990) 86:1423-7. doi: 10.1172/JCI114857

12. Li R, Xia J, Zhang X, Gathirua-Mwangi WG, Guo J, Li Y, et al. Associations of muscle mass and strength with all-cause mortality among US older adults. Med Sci Sport Exerc. (2018) 50:458-67. doi: 10.1249/MSS.0000000000001448

13. Paoli A, Tinsley G, Bianco A, Moro T. The influence of meal frequency and timing on health in humans: the role of fasting. Nutrients. (2019) 11:719. doi: 10.3390/nu11040719

14. Tinsley GM, La Bounty PM. Effects of intermittent fasting on body composition and clinical health markers in humans. Nutr Rev. (2015) 73:661-74. doi: 10.1093/nutrit/nuv041

15. Peterson CM. Intermittent fasting induces weight loss, but the effects on cardiometabolic health are modulated by energy balance. Obesity. (2019) 27:11. doi: 10.1002/oby.22384

16. Pellegrini M, Cioffi I, Evangelista A, Ponzo V, Goitre I, Ciccone G, et al. Effects of time-restricted feeding on body weight and metabolism. A systematic review and meta-analysis. Rev Endocr Metab Disord. (2020) 21:17-33. doi: 10.1007/s11154-019-09524-w

17. Welton S, Minty R, O'Driscoll T, Willms H, Poirier D, Madden S, et al. Intermittent fasting and weight loss Systematic review. Can Fam Physician. (2020) 66:117-25.

18. Rynders CA, Thomas EA, Zaman A, Pan Z, Catenacci VA, Melanson EL. Effectiveness of intermittent fasting and time-restricted feeding compared to continuous energy restriction for weight loss. Nutrients. (2019) 11:2442. doi: $10.3390 /$ nu11102442

19. Varady KA, Bhutani S, Church EC, Klempel MC. Short-term modified alternate-day fasting: a novel dietary strategy for weight loss and cardioprotection in obese adults. Am J Clin Nutr. (2009) 90:113843. doi: 10.3945 /ajcn.2009.28380

20. Sievert K, Hussain SM, Page MJ, Wang Y, Hughes HJ, Malek M, et al. Effect of breakfast on weight and energy intake: systematic review and meta-analysis of randomised controlled trials. BMJ. (2019) 364:142. doi: 10.1136/bmj.142

21. Ravussin E, Beyl RA, Poggiogalle E, Hsia DS, Peterson CM. Early time-restricted feeding reduces appetite and increases fat oxidation but does not affect energy expenditure in humans. Obesity. (2019) 27:124454. doi: 10.1002/oby.22518

22. Areta JL, Burke LM, Camera DM, West DWD, Crawshay S, Moore $\mathrm{DR}$, et al. Reduced resting skeletal muscle protein synthesis is rescued by resistance exercise and protein ingestion following short-term energy deficit. Am J Physiol Endocrinol Metab. (2014) 306:989-97. doi: 10.1152/ajpendo.00590.2013

23. Pasiakos SM, Vislocky LM, Carbone JW, Altieri N, Konopelski K, Freake HC, et al. Acute energy deprivation affects skeletal muscle protein synthesis and associated intracellular signaling proteins in physically active adults. J Nutr. (2010) 140:745-51. doi: 10.3945/jn.109.118372

24. Anton S, Leeuwenburgh C. Fasting or caloric restriction for Healthy Aging. Exp Gerontol. (2013) 48:1003-5. doi: 10.1016/j.exger.2013.04.011

25. Dethlefsen MM, Bertholdt L, Gudiksen A, Stankiewicz T, Bangsbo $\mathrm{J}$, van Hall G, et al. Training state and skeletal muscle autophagy in response to $36 \mathrm{~h}$ of fasting. J Appl Physiol. (2018) 125:160919. doi: 10.1152/japplphysiol.01146.2017

26. Møller AB, Vendelbo MH, Christensen B, Clasen BF, Bak AM, Jørgensen JOL, et al. Physical exercise increases autophagic signaling through ULK1 in human skeletal muscle. J Appl Physiol. (2015) 118:9719. doi: 10.1152/japplphysiol.01116.2014

27. Abdulla H, Smith K, Atherton PJ, Idris I. Role of insulin in the regulation of human skeletal muscle protein synthesis and breakdown: a systematic review and meta-analysis. Diabetologia. (2016) 59:4455. doi: 10.1007/s00125-015-3751-0

28. Wilkes EA, Selby AL, Atherton PJ, Patel R, Rankin D, Smith K, et al. Blunting of insulin inhibition of proteolysis in legs of older subjects may contribute to age-related sarcopenia. Am J Clin Nutr. (2009) 90:134350. doi: 10.3945/ajcn.2009.27543

29. Glynn EL, Fry CS, Drummond MJ, Dreyer HC, Dhanani S, Volpi E, et al. Muscle protein breakdown has a minor role in the protein anabolic response to essential amino acid and carbohydrate intake following resistance exercise. Am J Physiol Regul Integr Comp Physiol. (2010) 299:R53340. doi: 10.1152/ajpregu.00077.2010

30. Staples AW, Burd NA, West DWD, Currie KD, Atherton PJ, Moore $\mathrm{DR}$, et al. Carbohydrate does not augment exercise-induced protein accretion versus protein alone. Med Sci Sports Exerc. (2011) 43:115461. doi: 10.1249/MSS.0b013e31820751cb

31. Felig P, Marliss E, Pozefsky T, Cahill GF. Amino acid metabolism in the regulation of gluconeogenesis in man. Am J Clin Nutr. (1970) 23:98692. doi: $10.1093 / \mathrm{ajcn} / 23.7 .986$

32. Cahill GF. Starvation in man. Clin Endocrinol Metab. (1976) 5:397415. doi: 10.1016/S0300-595X(76)80028-X

33. Felig P, Owen OE, Wahren J, Cahill GF. Amino acid metabolism during prolonged starvation. J Clin Invest. (1969) 48:58494. doi: 10.1172/JCI106017

34. Biolo G, Zhang XJ, Wolfe RR. Role of membrane transport in interorgan amino acid flow between muscle and small intestine. Metabolism. (1995) 44:719-24. doi: 10.1016/0026-0495(95)90183-3

35. Odessey R, Khairallah EA, Goldbert AL. Origin and possible significance of alanine production by skeletal muscle. J Biol. (1974) 249:76239. doi: 10.1016/S0021-9258(19)81283-8

36. Bak AM, Møller AB, Vendelbo MH, Nielsen TS, Viggers R, Rungby J, et al. Differential regulation of lipid and protein metabolism in obese vs. Lean subjects before and after a 72-h fast. Am J Physiol Endocrinol Metab. (2016) 311:E224-35. doi: 10.1152/ajpendo.00464.2015

37. Carlson MG, Snead WL, Campbell PJ. Fuel and energy metabolism in fasting humans. Am J Clin Nutr. (1994) 60:29-36. doi: 10.1093/ajcn/60.1.29

38. Pozefsky T, Tancredi RG, Moxley RT, Dupre J, Tobin JD. Effects of brief starvation on muscle amino acid metabolism in nonobese man. J Clin Invest. (1976) 57:444-9. doi: 10.1172/JCI108295

39. Biolo G, Maggi SP, Williams BD, Tipton KD, Wolfe RR. Increased rates of muscle protein turnover and amino acid transport after resistance exercise in humans. Am J Physiol. (1995) 268(3 Pt 1):51420. doi: 10.1152/ajpendo.1995.268.3.E514

40. Phillips SM, Tipton KD, Aarsland A, Wolf SE, Wolfe RR. Mixed muscle protein synthesis and breakdown after resistance exercise in humans. Am J Physiol Metab. (1997) 273:E99-107. doi: 10.1152/ajpendo.1997.273.1.E99

41. Biolo G, Tipton KD, Klein S, Wolfe RR. An abundant supply of amino acids enhances the metabolic effect of exercise on muscle protein. Am J Physiol. (1997) 273(1 Pt 1):122-9. doi: 10.1152/ajpendo.1997.273.1.E122

42. Burd NA, Cermak NM, Kouw IWK, Gorissen SH, Gijsen AP, Van Loon LJC. The use of doubly labeled milk protein to measure postprandial muscle protein synthesis rates in vivo in humans. J Appl Physiol. (2014) 117:136370. doi: 10.1152/japplphysiol.00411.2014

43. Moore DR, Robinson MJ, Fry JL, Tang JE, Glover EI, Wilkinson SB, et al. Ingested protein dose response of muscle and albumin protein synthesis after resistance exercise in young men. Am J Clin Nutr. (2009) 89:1618. doi: 10.3945/ajcn.2008.26401

44. Witard OC, Jackman SR, Breen L, Smith K, Selby A, Tipton KD. Myofibrillar muscle protein synthesis rates subsequent to a meal in response to increasing doses of whey protein at rest and after resistance exercise. Am J Clin Nutr. (2014) 99:86-95. doi: 10.3945/ajcn.112.055517 
45. Moore DR. Maximizing post-exercise anabolism: the case for relative protein intakes. Front Nutr. (2019) 6:147. doi: 10.3389/fnut.2019.00147

46. Chan AH, D'Souza RF, Beals JW, Zeng N, Prodhan U, Fanning AC, et al. The degree of aminoacidemia after dairy protein ingestion does not modulate the postexercise anabolic response in young men: a randomized controlled trial. J Nutr. (2019) 149:1511-22. doi: 10.1093/jn/nxz099

47. Mitchell WK, Phillips BE, Williams JP, Rankin D, Lund JN, Smith K, et al. A Dose-rather than delivery profile-dependent mechanism regulates the "muscle-full" effect in response to oral essential amino acid intake in young men. J Nutr. (2015) 145:207-14. doi: 10.3945/jn.114.199604

48. Pennings B, Boirie Y, Senden JMG, Gijsen AP, Kuipers H, Van Loon LJC. Whey protein stimulates postprandial muscle protein accretion more effectively than do casein and casein hydrolysate in older men. Am J Clin Nutr. (2011) 93:997-1005. doi: 10.3945/ajcn.110.008102

49. West DWD, Burd NA, Coffey VG, Baker SK, Burke LM, Hawley JA, et al. Rapid aminoacidemia enhances myofibrillar protein synthesis and anabolic intramuscular signaling responses after resistance exercise. Am J Clin Nutr. (2011) 94:795-803. doi: 10.3945/ajcn.111.013722

50. Bilsborough S, Mann N. A review of issues of dietary protein intake in humans. Int J Sport Nutr. (2006) 16:129-52. doi: 10.1123/ijsnem.16.2.129

51. Pennings B, Groen BBL, Van Dijk JW, De Lange A, Kiskini A, Kuklinski M, et al. Minced beef is more rapidly digested and absorbed than beef steak, resulting in greater postprandial protein retention in older men. Am J Clin Nutr. (2013) 98:121-8. doi: 10.3945/ajcn.112.051201

52. van Vliet S, Beals JW, Holwerda AM, Emmons RS, Goessens JP, Paluska SA, et al. Time-dependent regulation of postprandial muscle protein synthesis rates after milk protein ingestion in young men. J Appl Physiol. (2019) 127:1792-801. doi: 10.1152/japplphysiol.00608.2019

53. Reitelseder S, Agergaard J, Doessing S, Helmark IC, Lund P, Kristensen NB, et al. Whey and casein labeled with L-[1-13C]leucine and muscle protein synthesis: effect of resistance exercise and protein ingestion. Am J Physiol Endocrinol Metab. (2011) 300:E231-42. doi: 10.1152/ajpendo.00513.2010

54. Bohé J, Aili Low JF, Wolfe RR, Rennie MJ. Latency and duration of stimulation of human muscle protein synthesis during continuous infusion of amino acids. J Physiol. (2001) 532:575-9. doi: 10.1111/j.1469-7793.2001.0575f.x

55. van Vliet S, Shy EL, Abou Sawan S, Beals JW, West DW, Skinner SK, et al. Consumption of whole eggs promotes greater stimulation of postexercise muscle protein synthesis than consumption of isonitrogenous amounts of egg whites in young men. Am J Clin Nutr. (2017) 106:140112. doi: 10.3945/ajcn.117.159855

56. Atherton PJ, Etheridge T, Watt PW, Wilkinson D, Selby A, Rankin D, et al. Muscle full effect after oral protein: time-dependent concordance and discordance between human muscle protein synthesis and mTORC1 signaling. Am J Clin Nutr. (2010) 92:1080-8. doi: 10.3945/ajcn.2010.29819

57. Witard OC, Tieland M, Beelen M, Tipton KD, J van LL, Koopman R. Resistance exercise increases postprandial muscle protein synthesis in humans. Med Sci Sport Exerc. (2009) 41:144-54. doi: 10.1249/MSS.0b013e3181844e79

58. Moore DR, Tang JE, Burd NA, Rerecich T, Tarnopolsky MA, Phillips SM. Differential stimulation of myofibrillar and sarcoplasmic protein synthesis with protein ingestion at rest and after resistance exercise. J Physiol. (2009) 587:897-904. doi: 10.1113/jphysiol.2008.164087

59. Pasiakos SM, Cao JJ, Margolis LM, Sauter ER, Whigham LD, McClung JP, et al. Effects of high-protein diets on fat-free mass and muscle protein synthesis following weight loss: a randomized controlled trial. FASEB J. (2013) 27:3837-47. doi: 10.1096/fj.13-230227

60. Trommelen J, Groen BBL, Hamer HM, de Groot LCPGM, van Loon LJC. Mechanisms in endocrinology: exogenous insulin does not increase muscle protein synthesis rate when administered systemically: a systematic review. Eur J Endocrinol. (2015) 173:R25-34. doi: 10.1530/EJE-14-0902

61. Nair KS, Woolf PD, Welle SL, Matthews DE. Leucine, glucose, and energy metabolism after 3 days of fasting in healthy human subjects. Am J Clin Nutr. (1987) 46:557-62. doi: 10.1093/ajcn/46.4.557

62. Boirie Y, Dangin M, Gachon P, Vasson M-P, Maubois J-L, Beaufrere B. Slow and fast dietary proteins differently modulate postprandial protein accretion. Proc Natl Acad Sci U S A. (1997) 94:14930-5. doi: 10.1073/pnas.94.26. 14930
63. Kim IY, Deutz NEP, Wolfe RR. Update on maximal anabolic response to dietary protein. Clin Nutr. (2018) 37:411-8. doi: 10.1016/j.clnu.2017.05.029

64. Mazzulla M, Volterman KA, Packer JE, Wooding DJ, Brooks JC, Kato H, et al. Whole-body net protein balance plateaus in response to increasing protein intakes during post-exercise recovery in adults and adolescents. Nutr Metab. (2018) 15:62. doi: 10.1186/s12986-018-0301-z

65. Areta JL, Burke LM, Ross ML, Camera DM, West DWD, Broad EM, et al. Timing and distribution of protein ingestion during prolonged recovery from resistance exercise alters myofibrillar protein synthesis. J Physiol. (2013) 591:2319-31. doi: 10.1113/jphysiol.2012.244897

66. Mamerow MM, Mettler JA, English KL, Casperson SL, Arentson-Lantz E, Sheffield-Moore M, et al. Dietary protein distribution positively influences 24-h muscle protein synthesis in healthy adults. J Nutr. (2014) 144:87680. doi: 10.3945/jn.113.185280

67. Moore DR, Areta J, Coffey VG, Stellingwerff T, Phillips SM, Burke LM, et al. Daytime pattern of post-exercise protein intake affects whole-body protein turnover in resistance-trained males. Nutr Metab. (2012) 9:915. doi: 10.1186/1743-7075-9-91

68. Moore DR, Churchward-Venne TA, Witard O, Breen L, Burd NA, Tipton KD, et al. Protein ingestion to stimulate myofibrillar protein synthesis requires greater relative protein intakes in healthy older versus younger men. Journals Gerontol Ser A Biol Sci Med Sci. (2015) 70:5762. doi: 10.1093/gerona/glu103

69. Trepanowski JF, Kroeger CM, Barnosky A, Klempel MC, Bhutani S, Hoddy KK, et al. Effect of alternate-day fasting on weight loss, weight maintenance, and cardioprotection among metabolically healthy obese adults: a randomized clinical trial. JAMA Intern Med. (2017) 177:9308. doi: 10.1001/jamainternmed.2017.0936

70. Bowen J, Brindal E, James-Martin G, Noakes M. Randomized trial of a high protein, partial meal replacement program with or without alternate day fasting: similar effects on weight loss, retention status, nutritional, metabolic, and behavioral outcomes. Nutrients. (2018) 10:1145. doi: 10.3390/nu10091145

71. Klempel MC, Kroeger CM, Varady KA. Alternate day fasting (ADF) with a high-fat diet produces similar weight loss and cardio-protection as ADF with a low-fat diet. Metabolism. (2013) 62:137-43. doi: 10.1016/j.metabol.2012.07.002

72. Varady KA, Bhutani S, Klempel MC, Kroeger CM, Trepanowski JF, Haus JM, et al. Alternate day fasting for weight loss in normal weight and overweight subjects: A randomized controlled trial. Nutr J. (2013) 12:146. doi: 10.1186/1475-2891-12-146

73. Tinsley GM, Moore ML, Graybeal AJ, Paoli A, Kim Y, Gonzales JU, et al. Time-restricted feeding plus resistance training in active females: a randomized trial. Am J Clin Nutr. (2019) 110:628-40. doi: 10.1093/ajcn/nqz126

74. Teng NIMF, Shahar S, Rajab NF, Manaf ZA, Johari MH, Ngah WZW. Improvement of metabolic parameters in healthy older adult men following a fasting calorie restriction intervention. Aging Male. (2013) 16:17783. doi: 10.3109/13685538.2013.832191

75. Klempel MC, Kroeger CM, Bhutani S, Trepanowski JF, Varady KA. Intermittent fasting combined with calorie restriction is effective for weight loss and cardio-protection in obese women. Nutr J. (2012) 11:98. doi: 10.1186/1475-2891-11-98

76. Teng NIMF, Shahar S, Manaf ZA, Das SK, Taha CSC, Ngah WZW. Efficacy of fasting calorie restriction on quality of life among aging men. Physiol Behav. (2011) 104:1059-64. doi: 10.1016/j.physbeh.2011.07.007

77. Heilbronn LK, Smith SR, Martin CK, Anton SD, Ravussin E. Alternate-day fasting in nonobese subjects: Effects on body weight, body composition, and energy metabolism. Am J Clin Nutr. (2005) 81:69-73. doi: 10.1093/ajcn/81.1.69

78. Bhutani S, Klempel MC, Kroeger CM, Trepanowski JF, Varady KA. Alternate day fasting and endurance exercise combine to reduce body weight and favorably alter plasma lipids in obese humans. Obesity. (2013) 21:13709. doi: 10.1002/oby.20353

79. Harvie MN, Pegington M, Mattson MP, Frystyk J, Dillon B, Evans G, et al. The effects of intermittent or continuous energy restriction on weight loss and metabolic disease risk markers: a randomized trial in young overweight women. Int J Obes. (2011) 35:714-27. doi: 10.1038/ijo.2010.171 
80. Catenacci VA, Pan Z, Ostendorf D, Brannon S, Gozansky WS, Mattson $\mathrm{MP}$, et al. A randomized pilot study comparing zero-calorie alternate-day fasting to daily caloric restriction in adults with obesity. Obesity. (2016) 24:1874-83. doi: 10.1002/oby.21581

81. Moro T, Tinsley G, Bianco A, Marcolin G, Pacelli QF, Battaglia G, et al. Effects of eight weeks of time-restricted feeding (16/8) on basal metabolism, maximal strength, body composition, inflammation, and cardiovascular risk factors in resistance-trained males. J Transl Med. (2016) 14:290. doi: 10.1186/s12967-016-1044-0

82. Davis CS, Clarke RE, Coulter SN, Rounsefell KN, Walker RE, Rauch CE, et al. Intermittent energy restriction and weight loss: a systematic review. Eur J Clin Nutr. (2016) 70:292-9. doi: 10.1038/ejcn.2015.195

83. Alhamdan BA, Garcia-Alvarez A, Alzahrnai AH, Karanxha J, Stretchberry DR, Contrera KJ, et al. Alternate-day versus daily energy restriction diets: which is more effective for weight loss? A systematic review and metaanalysis. Obes Sci Pract. (2016) 2:293-302. doi: 10.1002/osp4.52

84. Tavoian D, Ampomah K, Amano S, Law TD, Clark BC. Changes in DXA-derived lean mass and MRI-derived cross-sectional area of the thigh are modestly associated. Sci Rep. (2019) 9:10028. doi: 10.1038/s41598-019-46428-w

85. Mahon AK, Flynn MG, Iglay HB, Stewart LK, Johnson CA, Mcfarlin $\mathrm{BK}$, et al. Measurement of body composition changes with weight loss in postmenopausal women: comparison of methods. J Nutr Heal Aging. (2007) 11:203-13.

86. Evans EM, Saunders MJ, Spano MA, Arngrimsson SA, Lewis RD, Cureton KJ. Body-composition changes with diet and exercise in obese women: a comparison of estimates from clinical methods and a 4-component model. Am J Clin Nutr. (1999) 70:5-12. doi: 10.1093/ajcn/70.1.5

87. Lowe DA, Wu N, Rohdin-Bibby L, Moore AH, Kelly N, Liu YE, et al. Effects of time-restricted eating on weight loss and other metabolic parameters in women and men with overweight and obesity. JAMA Intern Med. (2020) 180:1491-9. doi: 10.1001/jamainternmed.2020.4153

88. Kim J, Wang Z, Heymsfield SB, Baumgartner RN, Gallagher D. Total-body skeletal muscle mass: estimation by a new dual-energy X-ray absorptiometry method. Am J Clin Nutr. (2002) 76:378-83. doi: 10.1093/ajcn/76.2.378

89. Cienfuegos S, Gabel K, Kalam F, Ezpeleta M, Wiseman E, Pavlou V, et al. Effects of 4- and 6-h time-restricted feeding on weight and cardiometabolic health: a randomized controlled trial in adults with obesity. Cell Metab. (2020) 32:366-378.e3. doi: 10.1016/j.cmet.2020.06.018

90. Tinsley GM, Forsse JS, Butler NK, Paoli A, Bane AA, La Bounty $\mathrm{PM}$, et al. Time-restricted feeding in young men performing resistance training: a randomized controlled trial. Eur J Sport Sci. (2017) 17:2007. doi: 10.1080/17461391.2016.1223173

91. James R, James LJ, Clayton DJ. Anticipation of $24 \mathrm{~h}$ severe energy restriction increases energy intake and reduces physical activity energy expenditure in the prior $24 \mathrm{~h}$, in healthy males. Appetite. (2020) 152:104719. doi: 10.1016/j.appet.2020.104719

92. Oikawa SY, Holloway TM, Phillips SM. The impact of step reduction on muscle health in aging: protein and exercise as countermeasures. Front Nutr. (2019) 6:75. doi: 10.3389/fnut.2019.00075

93. Keenan S, Cooke MB, Belski R. The effects of intermittent fasting combined with resistance training on lean body mass: a systematic review of human studies. Nutrients. (2020) 12:1-17. doi: 10.3390/nu12082349

94. Schoenfeld BJ. The mechanisms of muscle hypertrophy and their application to resistance training. J Strength Cond Res. (2010) 24:285772. doi: 10.1519/JSC.0b013e3181e840f3
95. Yasuda J, Tomita T, Arimitsu T, Fujita S. Evenly distributed protein intake over 3 meals augments resistance exercise-induced muscle hypertrophy in healthy young men. J Nutr. (2020) 150:1845-51. doi: 10.1093/jn/nxaa101

96. Mazzulla M, Sawan SA, Williamson E, Hannaian SJ, Volterman KA, West DWD, et al. Protein intake to maximize whole-body anabolism during postexercise recovery in resistance-trained men with high habitual intakes is severalfold greater than the current recommended dietary allowance. J Nutr. (2020) 150:505-11. doi: 10.1093/jn/nxz249

97. Morton RW, Murphy KT, McKellar SR, Schoenfeld BJ, Henselmans M, Helms E, et al. A systematic review, meta-analysis and meta-regression of the effect of protein supplementation on resistance training-induced gains in muscle mass and strength in healthy adults. Br J Sports Med. (2018) 52:376-84. doi: 10.1136/bjsports-2017-097608

98. Clark R V., Walker AC, O'Connor-Semmes RL, Leonard MS, Miller RR, Stimpson SA, et al. Total body skeletal muscle mass: estimation by creatine (methyl -d 3) dilution in humans. J Appl Physiol. (2014) 116:1605-13. doi: 10.1152/japplphysiol.00045.2014

99. Evans WJ, Hellerstein M, Orwoll E, Cummings S, Cawthon PM. D 3 Creatine dilution and the importance of accuracy in the assessment of skeletal muscle mass. J Cachexia Sarcopenia Muscle. (2019) 10:1421. doi: $10.1002 /$ jcsm. 12390

100. Hellerstein M, Evans W. Recent advances for measurement of protein synthesis rates, use of the 'Virtual Biopsy' approach, and measurement of muscle mass. Curr Opin Clin Nutr Metab Care. (2017) 20(3). doi: 10.1097/MCO.0000000000000370

101. Brook MS, Wilkinson DJ, Atherton PJ, Smith K. Recent developments in deuterium oxide tracer approaches to measure rates of substrate turnover. Curr Opin Clin Nutr Metab Care. (2017) 20:191-200. doi: 10.1097/MCO.0000000000000392

102. Beals JW, Burd NA, Moore DR, van Vliet S. Obesity alters the muscle protein synthetic response to nutrition and exercise. Front Nutr. (2019) 6:87. doi: $10.3389 /$ fnut.2019.00087

103. Shad BJ, Thompson JL, Breen L. Does the muscle protein synthetic response to exercise and amino acid-based nutrition diminish with advancing age? A systematic review. Am J Physiol Metab. (2016) 311:E803E17. doi: 10.1152/ajpendo.00213.2016

104. Loenneke JP, Loprinzi PD, Murphy CH, Phillips SM. Per meal dose and frequency of protein consumption is associated with lean mass and muscle performance. Clin Nutr. (2016) 35:1506-11. doi: 10.1016/j.clnu.2016. 04.002

105. Longland TM, Oikawa SY, Mitchell CJ, Devries MC, Phillips SM. Higher compared with lower dietary protein during an energy deficit combined with intense exercise promotes greater lean mass gain and fat mass loss: a randomized trial. Am J Clin Nutr. (2016) 103:73846. doi: 10.3945/ajcn.115.119339

Conflict of Interest: The authors declare that the research was conducted in the absence of any commercial or financial relationships that could be construed as a potential conflict of interest.

Copyright (C) 2021 Williamson and Moore. This is an open-access article distributed under the terms of the Creative Commons Attribution License (CC BY). The use, distribution or reproduction in other forums is permitted, provided the original author(s) and the copyright owner(s) are credited and that the original publication in this journal is cited, in accordance with accepted academic practice. No use, distribution or reproduction is permitted which does not comply with these terms. 